\title{
An archaeological search for the emergence of early humans in West Africa
}

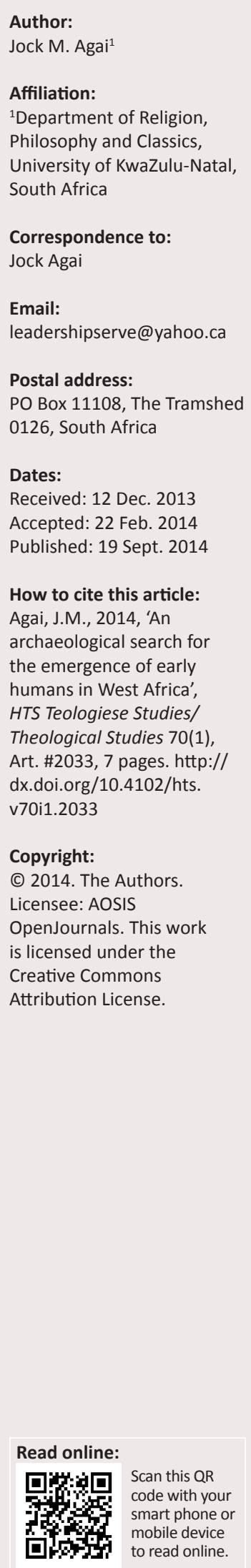

Fossils of early humans and their ancestors dating back to millions of years have not yet been found in West Africa. Tools made of bones, stones, and wood suggesting use by early humans or their ancestors have however been found in some parts of West Africa. This research investigates the possible origins and West African indigenous influences on the manufacture and use of these tools. The purpose of this research is to stimulate interest into the study of West African archaeology and palaeontology.

\section{The emergence of early humans}

One of the strands of the biological theories of human evolution teaches that modern humans emerged firstly from non-living matter, evolving into minute organisms, followed by fishand ape-like beings to early humans, and then modern humans. For example, an aspect of the biological theory of evolution called 'the theory of spontaneous generation' of life proposed by Aristotle teaches that the first life on earth came into being by itself (spontaneously) and from a non-living matter catalyst known as 'active principle' (Welch 1963:87). Other scientists propose that the first life emerged from meteorites whilst others say it emerged from pre-existing matter through the process of biogenesis. Other scientists are of the opinion that life first emerged from ancient waters which was surrounded by protein molecules (cf. Welch 1963:90; Agai 2005:61-71). ${ }^{1}$ Primates are popularly believed to be monkeys which advanced into apes and other ape-like beings: many scientists are of the opinion that certain apes and ape-like creatures evolved into early humans through some intermediately progressive stages in this hierarchy: tarsiers - Esomias - New World monkeys - Old World monkeys - gibbons - orangutans - gorillas - chimpanzee early humans - modern humans (Gore 2003:37).

The first primate still has to be discovered: some biologists however suggest Esomias, the 'down ape' (a 40-million-year-old Chinese fossil) or Catopithecus (a 37-million-year-old Egyptian lemur) are the oldest primates on earth (Raven \& Johnson 1999:445-446). Other biologists say that the most distant ancestors of primates include Aegyptopithecus (which walked on four legs), Dryopithicines (which walked on four legs), and Ramapithecines (which is said to have flourished in Africa and Eurasia between 14 and 18 million years ago). Many fossils of Dryopithicines were found on the island of Lake Victoria, whilst only the jaw bone of Ramapithecines was found in Siwalik in Pakistan. David Pilbeam of Yale University in the United States did substantial research on the fossil-bearing rocks in the Siwalik Hills where he found much evidence that Ramapithecines are ancestors of the hominids. At Fort Ternan in Kenya, a 14-million-year-old specimen of Ramapithecines was found (Leakey 1982:20-23). ${ }^{2}$ These groups of early primates and many more are said have lived in trees and their constant facing of the sun developed their eyesight and stereoscopic vision to the extent that they could judge long distances and leap freely from one tree branch to another (Leakey 1982:9). About 6 million years ago, species of Ramapithecines then developed unique fingers, toes, a relatively large brain, and they reduced the number of their progenies to enable them to move easily from one tree to another (Leakey 1982:9-11). ${ }^{3}$

On the question of the origin of the split between humans and other primates, no one knows the precise date nor the specific reasons behind the split. Leakey (1982:23) says that by three to three-quarter million years ago, human ancestors were fully bipedal (walked on two legs).

\footnotetext{
1.In this research, early humans mean: beings or beings in the form of the Neanderthal man, the Peking man, Java man or the Grimaldi man; the ancestors of these early humans include Australopithecus africanus, Homo rudulfensis, Homo ergaster, Homo habilis, Homo erectus and Homo sapiens. The research will concentrate on the study of origins of early humans in Nigeria with a specific interest into the study of Homo neanderthalensis, and $H$. sapiens.

2.Around 6-9 million years ago, Ramapithecines might have left Pakistan due to extreme cold but those in Africa remained (Leakey 1982:20-23). Raven and Johnson (1999:446-447) believe that Ramapithecines were closely related to the Proconsul and that the Proconsul had many similarities with the Old World monkey, but lacked tails. Although it is believed that Ramapithecines survived in Africa and evolved into human ancestors, at the moment there is no evidence to show that this is true (Leakey 1982:22-23).

3. Humans advanced and their brain size developed more than other primates. For example, the cortex in humans remembers the past, plans for the future and solves most difficult and technical problems unlike other primates. It is the capacity of the human brain that
} explains its size relative to our bodies (Leakey 1982:9-11). 
Most scientists are of the opinion that there were major climatic changes in Eurasia and in East Africa between 6 and 8 million years ago, and that these changes created a new topographic environment in the Rift Valley of East Africa resulting in high mountains and densely-low grassy plains. These newly formed environmental surfaces created opportunities for the animals and primates to develop and adapt to the new environmental challenges. For example, the numerous species of Ramapithecines changed from walking on four legs to walking on two legs. The popular notion is that these changes took place in order to allow Ramapithecines to manufacture tools, but this view can be challenged because tools only appeared much later when the earliest human ancestors developed into apes. The change might have occurred to enable Ramapithecines to use their hands to carry, pick or grasp food or other objects and to prevent other animals or other Ramapithecines from taking their food (Leakey 1982:22-24). ${ }^{4}$ After millions of years those structurally adaptive changes led some ancestors of primates like Ramapithecines to evolve into apes and hominids and to early humans.

One of the most popular and best-known human ancestors is the A. africanus. They were small in size but their brain was relatively larger in proportion to their body size and they had the ability to stand erect and walked on two feet like later humans (Caldwell \& Gyles 1966:5). A. africanus fossils have been found in East Africa in 1959, in Ethiopia in 1974 and in South Africa in 1938 (Clark 1970:56; Raven \& Johnson 1999:450). What made them relevant in the search for early humans was their ability to use or manufacture tools. In 1947, Professor Wilfred was one of those who confidently announced that $A$. africanus were not hominids but apes (Raven \& Johnson 1999:454). Most researchers attribute the significance of $A$. africanus to their special ability to use tools. Raven and Johnson (1999:454) say that they had the ability to use tools but not manufacture them. Leakey (1982:31; cf. Clark 1970:56) also states that although A. africanus were more human-like than ape-like their small brain suggests that they were not very clever: hence they could not have manufactured tools, and had no features that should classify them as true human ancestors. Their ability to either use or manufacture tools and the fact that they were contemporaries of other early human ancestors make them relevant in the study of human origins. ${ }^{5}$

Other ancestors of early humans that emerged include $H$. rudulfensis, $H$. ergaster, $H$. habilis, $H$. erectus and H. sapiens. A skull of H. rudulfensis was found in northern Kenya in 1972 by Richard Leakey. It had a small skull and a brain capacity of 750 cubic centimeters with brain characteristics like those of a human skull and not that of A. africanus. The skull of $H$. ergaster shows that it had a larger brain size than those of $H$. rudulfensis. In addition, the skeleton of $H$. ergaster suggests that it had a skeleton less like $A$. africanus and more like a

4.Another possible reason for the rise of bipedalism could be the result of the high grass on the grass plains, hence walking upright enabled hominids to see further.

5.Leakey suggests that Australopithecus lived alongside other human ancestors (like H. habilis) for about 2 million years before their extinction (Leakey 1982:32). modern man in size and proportion. H. ergaster also had cheekbones and teeth like those of modern humans (Raven \& Johnson 1999:454). Henri de Lumley and his wife MarieAntoinette found part of a skull in a cave in the foothills of French Pyrenees. The skull seems to be late $H$. erectus or early $H$. sapiens and the unique characteristic about the cave was that it had more delicate tools than those used by $H$. erectus. The more skilfully made choppers (used for cutting and chopping) show evidence of being sharpened by early humans and then re-sharpened after a period of time, probably by another group of early humans. This suggests that there were gradual changes from $H$. erectus to $H$. sapiens which might have begun four hundred thousand years ago: one hundred thousand years ago skulls were found in some specific sites that were fully H. sapiens (Leakey 1982:52-54). How did this change occur?

The H. sapiens of Europe which lived between forty thousand and hundred thousand years ago are called Neandertals or Neanderthals ${ }^{6}$ (Leakey 1982:55). The fossils and tools of Neanderthals disappeared from the European fossil record thirty-five thousand years ago (Leakey 1982:59) and the only surviving Homo and hominid is H. sapiens (Raven \& Johnson 1999:458). ${ }^{7}$

There are at present still many questions that are to be answered concerning the origins of the Neanderthals and their relationship with other early humans who lived in Africa. There is a scientific school of thought which believes that at the beginning of the last ice age in Europe, H. sapiens encroached upon Neanderthals until they displaced them entirely before the end of that ice age. This school of thought proposes that some inbreeding took place between the Neanderthals and $H$. sapiens, as a result of which no trace of Neanderthal tradition remained when the ice receded (Caldwell \& Gyles 1966:12). Contemporary reconstruction conducted on Neanderthals fossils however revealed that the Neanderthals were more muscled and stronger than their contemporaries (the H. sapiens or the direct ancestors of modern humans), with a longer life span (Phillip 2000:2). Consequently, Denton says that it is illogical to think that $H$. sapiens, the ancestors of modern humans, overpowered the Neanderthals. Denton thinks that the Neanderthals had possessed greater intellectual and physical capacities to overpower H. sapiens, hence Neanderthals and H. sapiens lived together but did not inbreed with humans or human ancestors as speculated: they rather shared ideas (Denton 2013:4; cf. Leakey 1982:54).

Another scientific school of thought teaches that the Neanderthals were not in any way the ancestors of modern humans. This school of thought accepts that both the

6.The name is derived from 'the valley of the Neander,' a small river which runs into the river Dussel, not far from the city of Dusseldorf, West Germany (Leakey 1982:54).

7.H. sapiens had a modern skull with a vertical forehead and a brain that is both high and short. The brain capacity was almost the same as that of modern man, about 1550 cubic centimetres (Raven \& Johnson 1999:458). 
Neanderthals and $H$. sapiens emerged from a single source like two branches growing from a single tree until they diverged a million years ago. One group which emerged from Africa left for Europe where they developed adaptive features to Europe's weather and they are today referred to as the H. neanderthalis (Fox 2010:2). Fox says that the second group of human species, that is $H$. sapiens which remained in Africa also migrated to Europe thirty thousand years ago and because of their superior intellect overpowered European Neanderthals in competition for the scare resources in Europe during the ice ages (Fox 2010:2).

It is appropriate to note that whilst Neanderthals were living in Europe, other kinds of humans were living in Africa, and one of the best-known of these is the Rhodesian man found in a cave north of the river Zambesi in Broken Hill in Zambia. Other finds from Saldanha in South Africa, Ngaloba in Tanzania, and from Bodo and the Omo valley in Ethiopia show that some developed humans lived in Africa around the same time the Neanderthals lived in Europe and in Asia. ${ }^{8}$ The Broken Hill cave also contained remains of stone tools and extinct animal bones. The limb bones of the Rhodesian man were found to be straighter and more slender than those of the European Neanderthals, but his low skull and receding forehead is similar to those of the European Neanderthals. Most scientists have come to conclusion that the Rhodesian man '... was the African version of the aberrant Neanderthal type' (Constable 1973:22).

Neanderthal fossils have not been found in West Africa and the name Neanderthals is associated with Europe rather than Africa because the earliest fossils of the Neanderthals were found in Germany and other parts of Europe (Agai 2013:10). Although many more fossils of other early humans have been found in eastern, northern and southern Africa, the absence of a general name for these fossils made some researchers use the name 'Neanderthal' to describe some early humans living in Africa and which were the contemporaries of the European Neanderthals. This researcher also uses the name Neanderthals to refer to other early human fossils found in Africa because Neanderthals shared many similar features to those early humans found in Africa, and accepts that the European Neanderthals had contact with other early humans who lived in Africa. There is a need to begin to classify and study the African early humans comparatively but independently of the European Neanderthals.

\section{An inquiry into the archaeology of West Africa}

West Africa is a geographically vast region (consisting of Benin Republic, Burkina Faso, Cameroun, Cape Verde, Chad, Côte d'Ivoire, Equatorial Guinea, Gambia, Ghana, Guinea Bissau, Liberia, Mali, Mauritania, Niger, Nigeria, Senegal, Sierra Leone, Sao Tome and Principe, and Togo) where fossils of early humans are still to be found. This is unlike eastern, southern, and northern Africa where early human fossils and their ancestors were found (Shaw 2004:25). The absence of early human fossils in West Africa generally implies that early humans might not have lived in West Africa. Furthermore, the fact that the history of early travellers to West Africa was not documented or known (Shinnie 1965:76), as well as the non-permanent settlements of early European explorers on West African shores (Boateng 1978:10), suggest a low patronage of West African archaeology in comparison to how archaeology is patronised in other African regions and especially in southern Africa. Boateng adds that the climatic and other physical conditions of West Africa discouraged Europeans from settling permanently in West Africa:

Unlike the rest of the continent, especially East, Southern and North Africa, where the climatic and other physical conditions made permanent white settlement possible, West Africa never experienced permanent settlement by Europeans, and trade and other forms of economic exploitation remained the primary object of European colonising effort within the region. (Boateng 1978:102)

Many West African tribes and peoples are left with the option of relying on oral history, myths, legends, historical archaeology, some archaeological finds and informed speculation to relate to the origins of their cultures and of early humans who might have lived in West Africa. The informed speculation is the result of a prolonged neglect of the search for ancient migration routes within and into the African continent (cf. Le Roux 2008:3), and the lack of documentation of West African history even by classical writers who at one time dominated the literary world and who had travelled to many parts of the world, including West Africa (cf. Lange 2004:319).

The poor patronising of West African archaeology in comparison to other African regions made some scholars assume that many civilisations in West Africa are not indigenous. For example, iron deposits, the art of iron smelting and bronze-casting in West Africa are said to have originated with the Phoenicians or the Egyptians, and the art of livestock management in Asia (Guisepi 2001). Shaw states that the first metals to be used for tools and weapons were found in South-West Asia, Egypt and Europe and that the metals were basically bronze, hence 'Nigeria was not touched by Bronze Age' (Shaw 2004:36). He emphasises that the knowledge of iron reached Nigeria only between $400 \mathrm{BC}$ and 700 AD (Shaw 2004:36). However, both Shaw and Guisepi (2001) recognise an additional indigenous knowledge in the art of metals in West Africa although the art itself did not originate in West Africa. Likewise certain animals like goats and sheep found in West Africa are said to have originated from Asia and horses were introduced by the Hyksos from Egypt (Guisepi 2001).

A number of tribes in West Africa, and in Nigeria in particular, do not believe that their tribes and culture have indigenous origins: they link the origins of their culture to some recognised ancient civilised world, and their aim is to associate themselves with the glory and civilisations of other peoples. For example, the Ibo people (south-eastern Nigeria) believe that they and their culture originated in Israel (Umoh 
1971:163-164) whilst the Hausas (northern Nigeria) rely on the Bayajidda legend which teaches that the ancestors of the Hausas came originally from Canaan (Lange 2004:215-216). The Yorubas (south-western Nigeria) on the other hand claim that their ancestors and culture originated in Egypt or Mecca (Agai 2013:1-2). The Oduduwa legend which teaches that the ancestors of the Yorubas originated in Mecca has recently attracted less popularity as many writers of Yoruba history are beginning to believe that whenever 'Mecca' or 'East' is mentioned with regard to Yoruba history, it implies Egypt and not literally Mecca (Folorunso 2003:83; Johnson 2001:5; Umoh 1971:116). The absence of archaeological evidence for contact between ancient Egypt and Nigeria (Parrinder 1951:200) and the much-blurred chronological coherence between these two cultures suggest that Nigeria was not in any way 'colonized' by Egypt (Shaw 2004:36). Although Shaw admits that certain metals and the art of casting metals are not of Nigerian origin, he encourages Nigerians and writers of Nigerian history not to look necessarily elsewhere as the basis for civilisation in Nigeria. He adds:

It is not true that Nigerian culture is lacking: ... fabulous prices are paid for Nigerian works of art in the Western world. Nigeria possesses her own glories and needs no borrowed light from other cultures. (Shaw 2004:36)

Nigeria is a multicultural and multi-religious country with over 250 ethnic groups. The population of Nigeria is over 150 million, making it the most populous nation in Africa and the eight most populous nation of the world. The three main tribes are the Ibos, the Yorubas, and the Hausas: there are however other other tribes in Nigeria such as the Berom, Tivs, Angas and many more (cf. Aliogo 2012:20, 26). The name of Nigeria has several possible origins:

- The river Niger which was named during the 2nd century AD from a Latin word Nigir or Nigeir meaning black (Omolewa 2008:11-12).

- The word Niger which is associated with black as is the case with Simeon, who was described as a Niger, a term associated with a black person (cf. Ac 13:1; Omolewa 2008:11-12).

- African people might have borrowed the name from the Greek word Naghar which also meant black (Omolewa 2008:11-12).

A British journalist and reporter for the London Times newspaper, Flora Shaw, was the first to use the name Nigeria (Omolewa 2008:12). Lagos was annexed in 1861 through the declaration of two separate protectorates which were amalgamated on 01 January 1914 and, from then, the country's name formally became 'Nigeria' (Murray 1981:147). The uniqueness of Nigeria and its people is important when it comes to understanding Africa's anthropology and archaeology. ${ }^{9}$ West African historical

9.For example, the Yorubas of Nigeria are described as the most outstanding people of "Black Africa" with respect to their myths' (Lange 2004:39). The Yorubas cautiously preserve their tradition and have influenced many people around the world by not easily adapting to other cultures. Ade (2006:3) says that '[no] African group has had greater influence on the culture of the New World than the Yoruba .... In addition, the annual Argungu fishing festival in Sokoto, the Dango festival in Kebbi, the Gani festival in Daura, the Ergungu festival in Yorubaland, the Bayajidd legend, the Oduduwa legend, and many more, are legends and festivities that are thought to have originated from the Semitic peoples (cf. Lange 2004:156-187). A proper channeling of these events and knowledge can boast Nigeria's tourism sector, promote Africa's cultural studies, and enhance research on the speculated connections between Nigeria and the ancient Near-East. archaeologists are strongly of the opinion that West Africa has much to contribute to the study of African history (Wesler 2002:24). Possible political reasons, limited archaeological interest, and the non-preservation of many archaeological sites in Nigeria have contributed to the existing low-regard for public archaeology in Nigeria. Wesler describes West African and especially Nigerian historical archaeology as a struggling field which is just starting. He adds that the lack of expertise in the scientific study of artifacts, too much reliance on oral history and 'Africanist archaeology' where culture, and especially linguistics, serve as data or evidence, result in substantial challenges when it comes to obtaining specific precision in understanding Nigerian archaeology (Wesler 2002:2, 3, 8, 19-24). The inadequate nature of institutional support and poor funding for Nigerian archaeology (Wesler 2002:25) has furthermore contributed to Africa and the world not sufficiently tapping into the rich cultures of the Nigerian people. Whilst reviewing the impact of archaeology in Nigeria, it has been noted that '... [ $t$ ] he absence of archaeology in the informal education spheres had made it impossible to tap the popularity that archaeology could well enjoy among Nigerian people' (Hall 1996:45).

\section{Were there early humans in Nigeria?}

Fossils of early humans have not yet been found in Nigeria, hence researchers at present rely on wood, stone, and bone tools in order to prove the possible habitation in Nigeria of early humans. Evidence from tools made of wood is rare because of the inability of wood to survive varying temperatures for long periods. Bone tools may survive longer than wood but the soil condition of most parts of Nigeria militates against their survival: stone tools survive longer (Shaw 2004:25). During the Paleolithic period early humans developed four fundamental traditions of stone tools: pebble-tool; bifacial-tool or hand-axe; flake-tool; and blade-tool (Guisepi 2000). Falola and Heaton (2010:17-18) stressed that early pioneers of Nigeria used tools made of wood, bones and stones. Shaw (2004:25-26) further enunciated that, in Nigeria, stone tools were mostly used in the form of pebbles or lumps and for chopping and cutting. Omolewa (2008:15) confirmed that early stone tools used for hunting were found in the following parts of Nigeria: JosPlateau, Afikpo in Imo, Iwo Eleru in Ondo, and Mejiro in Old Oyo state. Generally, the formed edges of these stone tools found in Nigeria are popularly known as Oldowan type tools named after the Olduvai Gorge in Tanzania (Omolewa 2008:15; cf. Leakey 1982:33).

In 1960, Jonathan Leakey found the jaw, leg, hand, and foot bones of a young child in East Africa. The specimen did not have massive teeth or strong skull ridges but a large brain capacity and the Leakeys thought that it was the fossil of $H$. habilis which means 'skilful man.' The scientific world doubted Leakey's findings and the classification of the fossil 
until 1972 when Bernard Ngene found a 2-million-yearold H. habilis skull at Lake Turkana in Kenya with similar features to the ones found by Leakey (Leakey 1982:33). ${ }^{10}$

Some writers of Nigerian history think that the stone tools found in Nigeria are exactly the same as those found in the Olduvai George (Falola \& Heaton 2010:18, 19; cf. Omolewa 2008:15). If this assertion is accepted, it suggests that the Nigerian stone tools might have been used about 2 million years ago and that they may either have been used or manufactured by $H$. habilis or related beings or contemporaries. Shaw (2004) however calls for restrain when making the East African and the West African stone tools comparisons. He argues that there is no genuine evidence at present that the dating of Olduvai George tools is similar to those found in Nigeria despite their similar physical features (Shaw 2004:26).

Another word which describes the kinds of tools and remains found in the Oldowan industry is 'Acheulian.' The Acheulian tools like the Oldowan tools are basically stone tools, oval or pointedly oval with a cutting edge around. These physical features suggest that Acheulian tools were carefully trimmed from both sides. One variety of these stone tools is known as 'cleavers' with straight transverse cutting edges (Shaw 2004:26). Omolewa says that the stone tools found in Nigeria are similar to those found in Saint Acheul in northern France: hence Acheulian. Omolewa thinks that the stone tools found in Nigeria were used during the same period to those found in Saint Acheul (Omolewa 2008:15). Omolewa, however, does not present detailed information on the process of the dating of the stone tools found in both France and in Nigeria. Archaeologists are of the opinion that Acheulian implements were basically manufactured by H. erectus (Shaw 2004:26) and that it is likely that other ancestors of early humans who had the ability to make tools also made or used Acheulian tool types.

Who were the H. erectus? One of the most important hominids of the genus Homo is H. erectus, with a larger brain than any other Homo except $H$. sapiens. Some biologists believe that $H$. erectus was a true hominid (Raven \& Johnson 1999:456) using fire and walking with a striding gait (Mader 1988:634-637). The Java man is an example of a distant progeny of $H$. erectus with a straight and excellent walking ability, in addition to a larger brain capacity (Raven \& Johnson 1999:456). H. erectus are said to have evolved into $H$. sapiens around four hundred thousand years ago (Leakey 1982:54). Evidence for the existence of $H$. erectus or related beings have not been found in Nigeria, and there is no categorical clarity that the Acheulian implements found in Nigeria are dated the same as those

10.Olduvai Gorge type tools are those said to be used by probably Australopithecines and $H$. ergaster, $H$. rudulfensis, $H$. habilis and mostly by $H$. erectus who lived over
five hundred thousand years ago (cf. Raven \& Johnson 1999:454; Leakey 1982:32five hundred thousand years ago (cf. Raven \& Johnson 1999:454; Leakey 1982:32-
33 ; 54). The brain size of the skull found by Ngene is 800 cubic centimeters, that $33 ; 54)$. The brain size of the skull found by Ngene is 800 cubic centimeters, that
is almost twice as big as the $450-500$ cubic centimeters of the Australopithecines: this suggests that $H$. habilis were tool makers (Leakey 1982:32-33). Raven and this suggests that $H$. habilis were tool makers (Leakey 1982:32-33). Raven and
Johnson (1999:454) state that the longer arms, legs, and skeleton system of $H$. habilis suggest that they manufactured and used tools. found in eastern, southern and northern Africa, or France. The fact that most of the stone tools were never discovered in their purest form (Guisepi 2000) suggests the possibility of unsystematic views with regard to the interpretation of the sources and use of the stone tools found in Nigeria.

The period through which the Acheulian industry prevailed had an impact in the north of the Sahara (Shaw 2004:26). Early human ancestors are said to have lived between 1 million (cf. Guisepi 2000) and 2 million years ago (cf. Leakey 1982:33) but not more than 6-8 million years ago when the earliest ancestors of early humans developed into apes (cf. Leakey 1982:22-24). It is assumed that sometime during the last period of the European ice age, high rainfall occurred in the northern Sahara resulting in the southward movement of the desert region of the Sahara. This climatic event produced an environment that was unattractive for the survival of early humans, leading to a substantial migration amongst those early humans living there (Shaw 2004:26). This climatic change which marked the end of the last glacial period contributed to the gradual domestication of plants and animals and the formation of settled communities at various times in certain places (Guisepi 2000). This could be the reason why Falola and Heaton (2010:17-18) stress that, during the late Stone Age, ${ }^{11}$ there was an unprecedented desertification of the Sahara which caused residents to migrate southward from the savannah into the forest zone. The drying up of the Sahara had pushed many people to migrate into sub-Saharan Africa. Guisepi (2001) thinks that those people who migrated from the Sahara into many parts of sub-Saharan Africa were the ancestors of the Negro peoples. ${ }^{12}$

The high regions of Nigeria's Jos-Plateau and its surroundings which might not have experienced the severe effect of the desertification of the northern Sahara should be referred to specifically: an open or lightly wooded grass land generally conducive for Acheulian humans might thus have been formed on the Jos-Plateau (Shaw 2004:26). For example, at Mai Idon Toro in Jos-Plateau, two layers of gravel (11 metres above the present river level) separated by a clay layer produced cleavers which outnumbered other tools found in other parts of Nigeria. At Pingell, in the northern region of Jos-Plateau more bifaces than cleavers were found and off the Plateau in the Nok valley more Acheulian materials in the form of cleavers. A radiocarbon dating of the Nok valley materials specifically obtained from carbonised wood found in this gravel indicates a dating above thirty-nine thousand years. Thurstan Shaw ${ }^{13}$ believes that the cleavers found in the region of Jos-Plateau, including those found at Ngalda near

11.After the emergence of modern humans there could have been anothe desertification period which had some connection with the climatic changes resulting from the earlier glacial period.

12.The climatic variation of the West African region which comprises some deserts and dense forests with frequent heavy rain-fall, and the tropical rain forest of some borders of Nigeria, could have supported the habitation of gorillas and other early borders of Nigeria, could have supported the habitation of gorillas and other early including the old Yorubaland (cf. Shinnie 1965:76) might have attracted early humans as well.

13.Thurstan Shaw was a professor of archaeology who conducted a number of Thurstan Shaw was a professor of archaeology who conducted a number of
excavations in Nigeria. He helped to start the department of archaeology at the distinguished University of Ibadan in Nigeria from where the study of archaeology spread to other institutions in Nigeria. 
Gongola, could not have been used before 150000 BC but rather at about 65000 BC (Shaw 2004:26-27).

It is likely that the high mountains of Jos-Plateau and its surroundings prevented or checked the impact of the Saharan desertification. As a result, early humans who lived over forty-five thousand years ago inhabited these regions of Nigeria. This researcher is of the opinion that the ancestors of early humans particularly $H$. habilis, $H$. erectus and H. sapiens, and the Neanderthal Man or similar species lived in Nigeria: they were likely responsible for the manufacture of the stone and bone tools found in many parts of Nigeria and their subsequent use, especially within the Jos-Plateau regions, for the following reasons:

- Although a thorough archaeological examination is yet to be conducted on these sites the abundance of cleavers found at Mai Idon Toro and at Pingell is likely 'indirect' evidence that early humans in the form of $H$. erectus, the African type of the Neanderthals or even $H$. sapiens made or used these artifacts within these regions of Jos-Plateau.

- The cleavers found in Jos-Plateau and its surrounding environment were used about sixty-five thousand years ago (cf. Shaw 2004:26-27). Neanderthals and their contemporaries lived between forty thousand and hundred thousand years ago (Leakey 1982:55), that is within the same period the cleavers were used. Omolewa (2008) says that reports by previous archaeologists suggest that Nigeria was inhabited as far back as 65000 $\mathrm{BC}$, that is over sixty-two thousand years ago: around the same period Neanderthals and other contemporaries of early humans like H. sapiens lived (Denton 2013:4). Omolewa believes that Nigeria was part of the Stone Age civilisation (cf. Omolewa 2008:15)..$^{14}$

- At present Jos-Plateau has the best climatic and weather conditions in Nigeria which is conducive for the survival of humans. Jos has been described as 'one of the healthiest places in West Africa' (Je'adayibe \& Kudu 2013:3). The increased rainfall during the first glacial age may have created steppes, savannahs, and lakes in the Sahara and may have opened routes across previously impassable deserts thus aiding migrations to other places. About 1.5-2.5 million years ago, European climate started to 'oscillate' as a result of the impact of the glaciers thereby creating extreme cold and heat in many parts of the world including the Sahara (Pfeiffer 1970:100-103). During the period four hundred thousand to seven hundred thousand years ago, there were also strong climatic upheavals in the African Rift Valley (Pfeiffer 1970:93-94). West Africa, specifically the high mountain-plains and plateaux of the Jos-Plateau region, might have experienced a lesser impact because of its topographic formations, hence a possibly suitable habitat for early humans and animals during those periods. ${ }^{15}$ More geological research is needed in this regard.

14.Omolewa (2008:15) thinks that humans in Nigeria have advanced from early Stone Age where they used stone tools to the early Iron Age where they began to use metals.

15.Shaw (2004:25-26) says that the geological evidence found in some parts of Nigeria (at Beli, on the river Taraba) shows that the age of some rock deposits in Nigeria is similar to the Oldowan type tools.
- Other writers like Clark, Guisepi and Agai admit to the possibility that Neanderthals or similar early humans lived in West Africa, and possibly in Nigeria in particular. With regard to the search for early humans, Clark (1970:120-122) suggests that Neanderthals lived in the higher regions of West Africa and argues that West Africa is the place where the African Negro evolved from Neanderthal species (cf. Guisepi 2001). ${ }^{16}$ Agai (2013:9) wrote an article concerning the origins of Yoruba afterlife beliefs and he came to the conclusion that the Egyptians were not responsible for introducing the afterlife culture amongst the Yorubas. He suggests that Neanderthals introduced or influenced Yoruba ancestors into believing in the afterlife: Agai however did not state the chronological order of this cultural passage. Agai (2013:1-9) believes that Neanderthals lived in Nigeria and in Yorubaland, in the Oyo and Ondo states where Oldowan tool types were found. Clark, Guisepi, and Agai did not provide archaeological evidence in the form of Neanderthal fossils, but relied on evidence based on climatic conditions, stone tools and cultural connections to suggest that Neanderthals lived in West Africa.

- Evidence of the existence of early humans and their ancestors have been found in northern, eastern, and southern Africa (Leakey 1982:59-60). It makes sense to suggest that because early humans and their ancestors lived in those regions of Africa, they should have lived in West Africa as well. ${ }^{17}$

\section{Conclusion}

The possible existence of early humans and their ancestors in Nigeria suggests that those early humans might have developed ways of meeting their daily needs. Their demands for food, water, shelter, defence and escape from natural disasters would have assisted them in developing features and skills relevant for their survival. This might have led to intellectual development, cultural growth, and the production of tools with an expectant progress in the technology for the manufacture and use of tools. This suggests that early humans in Nigeria had forms of civilisations. Through the process of biological evolution, modern humans are said to have emerged from early humans: likewise their cultural and technological origins. Virtually nothing or very little is known about early human civilisation in Nigeria except certain technologies produced by modern humans. For example, many writers have voiced the opinion that Nigerians, their cultures, and their technologies (the Nok terracotta [500 BC 200 AD], Ife bronze arts, etc.) originated from other parts of the world with some incorporation of indigenous knowledge.

16.Other researchers think that Neanderthals had no impact on the genealogy of modern human origins. For example, Szalay (2013:3) says that the average modern African has no Neanderthal DNA.

17.With regard to the existence of early humans, there has been limited archaeological research in Africa (and especially in West Africa). Leakey says that European archaeologists have been looking for remains in Europe for over 100 European archaeologists have been looking for remains in Europe for over 100 years unlike Africa that started its archaeological search for early human remains a few years ago (Leakey 1982:54). This is the main reason why less evidence of the survival of early humans and their ancestors has been found in West Africa. This researcher believes that as more archaeological excavations are conducted in Nigeria, fossils and other evidence of the existence of early humans could possibly be found. Unfortunately, many archaeological sites, especially in Nigeria, are not well preserved and this may hamper future research. 
If early humans had lived in Nigeria, it means that they might have influenced the thinking of modern humans and they might have developed their own civilisations as well. The Nok terracottas and the Ife bronze are for example manufactured by modern humans. The technologies of these works of art can be indigenous as well, and that is why '... archaeologists are looking at the possibility that West Africans developed iron-working technology autonomously, possibly starting with the Nok' (Atwood 2013:14). ${ }^{18}$ Regarding the creation of the state, Falola and Heaton (2010:37) say that '... all social state formations in the Nigerian region had essentially indigenous African origins, although they were certainly willing to incorporate outside influences over time.' This researcher believes that there are many factors, and items buried in Nigerian soil, which would support the theory that early humans and their ancestors lived in Nigeria. More archaeological research needs to be conducted on the subject especially on how the assumedly early humans in Nigeria influenced the creative thinking of modern humans. ${ }^{19} \mathrm{~A}$ thorough archaeological study also needs to be conducted on the history, the geological formations and the age of the JosPlateau mountain-plains: likewise on the cultures and on the many artifacts accidentally discovered in various locations around the Jos-Plateau and its surroundings, said to have been used by ancient peoples who lived on the Plateau.

\section{Acknowledgements Competing interests}

The author declares that he has no financial or personal relationship(s) that may have inappropriately influenced him in writing this article.

\section{References}

Ade, D.P., 2006, 'Change and continuity: The Yoruba belief in life after death', lecture held at the Metanexus Institute Philadelphia, 03-07 June, pp. 1-15, available from www.scrfibd.com/doc/59067767/Dopa-Mu

Agai, J.M., 2005, 'Christian responses to the biological theory of human evolution', MTH thesis, Department of Church History, Theological College of Northern Nigeria.

Agai, J.M., 2013, 'An investigation into the ancient Egyptian cultural influences on the Yorubas of Nigeria', HTS Teologiese Studies/Theological Studies 69(1), 9 pages. http://dx.doi.org/10.4102/hts.v69i1.1919

18.Originally from Roger Atwood, Archaeology 64(4), July/August 2011

19.Omolewa (2008:16) summarised the evolutionary development of the early humans in Nigeria by saying that these were creative people who made stone tools for themselves and used them for hunting and gathering wild fruits. They developed metal tools and advanced into agriculture, stock keeping and developed ways of food preservation. They also began to organise social control and began to create communities which later led to the emergence of groups and classes. Omolewa did not state categorically that early humans like the Neanderthals made the stone tools found in Nigeria. In the view of this researcher, Omolewa might have implied this.
Aliogo, J.E., 2012, Up to date current affairs, Dejoe Publication, Enugu.

Atwood, R., 2013, 'The Nok of Nigeria: West Africa's earliest-known civilization', The Digging Stick 30(1), 13-14.

Boateng, E.A., 1978, A political geography of Africa, Cambridge University Press, London.

Caldwell, E. \& Gyles W., 1966, The ancient world, Holt, Rinehart \& Winston Inc., New York.

Clark, J.D., 1970, The prehistory of Africa: Ancient peoples and places, vol. 72, G. Daniel (ed.), Thames and Hudson, London.

Constable, G., 1973, The Neanderthals: The emergence of man, Time Life, New York.

Denton, J., 2013, 'Carbon 14 dating? Neanderthal = Nephilim?', viewed 07 December 2013, from http://www/bibliotecaplyeyades.net/vida_alien/alien_watchers06. htm

Falola, T. \& Heaton, M.M., 2010, A history of Nigeria, Cambridge University Press, Cambridge.

Folorunso, C. A., 2003, 'Views of ancient Egypt from a West African perspective,' in D. O'Connor \& A. Reid (eds.), Ancient Egypt in Africa, pp. 77-94, University College London, London.

Fox, S., 2010, 'Who were the Neanderthals?', in Live Science, viewed 07 December 2013, from http://www.livescience.com/32574-who-were-the-neanderthals. html

Gore, R., 2003, 'The rise of mammals,' National Geographic 203(4), 2-37.

Guisepi, R.A., 2000, 'Prehistoric cultural stage, or level of human development, characterized by the creation and use of stone tools', viewed 16 May 2013, from http://stoneage.htm.

Guisepi, R.A., 2001, (ed.), The spread of civilization in Africa, in International World History Project, viewed 16 May 2013, from http://history-world.org/africa1.htm

Hall, M., 1996, Archaeology Africa, David Philip, Cape Town.

Je'adayibe, G.D., \& Kudu A., 2013, 'Sliding towards Armageddon: Revisiting ethnoreligious crises in Nigeria', viewed 06 May 2013, from www.abriefhistoryofjos. mhtm.

Johnson, S., 2001, The history of the Yorubas: From the earliest times to the beginning of the British protectorate, O. Johnson (ed.), CSS, Abuja.

Lange, D., 2004, Ancient kingdoms of West Africa: Africa-centred and CanaaniteIsraelite perspectives, a collection of published and unpublished studies in English Israelite perspectives, a collection
and French, J.H. Roll, Dettelbach.

Leakey, R. E., 1982, Human origins, Hamish Hamilton, London.

Le Roux, M., 2008, 'Ancient near eastern influence in sub-Saharan Africa', Ekklesiastikos Pharos 90(19), 1-20.

Mader, S.S., 1988, Inquiry into life, Wm.C. Brown Publishers, lowa.

Murray, J. (ed.), 1981, Cultural atlas of Africa, Oxford Press, Phaidon.

Omolewa, M., 2008, Certificate history of Nigeria, Longman, Ikeja.

Parrinder, G., 1951, West African psychology: A comparative study of psychological and religious thought, Lutterworth, London.

Pfeiffer, J.E., 1970, The emergence of man, Thomas Nelson \& Sons, Nairobi.

Phillip, D., 2000, 'Neanderthals are still human!', Acts \& Facts 29(5), viewed 15 December 2013, from http://www.icr.org/article/neanderthals-are-still-human/

Raven, P. H. \& Johnson, B. G., 1999 Biology, 5th edn., WCB McGraw-Hill, New York.

Shaw, T., 2004, 'Prehistory', in O. Ikime (ed.), Groundwork of Nigerian history, pp. 25-53, Heinemann Educational Books, Jos.

Shinnie, M., 1965, Ancient African kingdoms, Edward Arnold, London.

Szalay, J., 2013, 'Neanderthals: Facts about our extinct human relatives', in Live Science, viewed 18 December 2013, from http://www.livescience.com/28036neanderthals-facts-about-our-extinct-human-relatives.html

Umoh, S.M., 1971, 'Nigeria's multi-ethno-cultural communications system and its influence upon social and business behaviour', PhD dissertation, Department of Communications, United State International University.

Welch, C., 1963, Biological science: Molecules to man, Houghton Mifflin Company, Boston.

Wesler, K.W., 2002, 'Historical archaeology in West Africa', in A.A. Idrees \& Y.A. Ochefu (eds.), Studies in the history of central Nigeria area, vol. 1, pp.1-39, CSS, Lagos. 